\title{
UJI BIOAKTIVITAS EKSTRAK Padina australis DARI PESISIR PANTAI MOLAS SULAWESI UTARA TERHADAP BAKTERI Staphylococcus epidermidis
}

\author{
(Bioactivity Test of Padina australis Extract Obtained from Molas Coast of North \\ Sulawesi, Against Bacterium Staphylococcus epidermidis)
}

\author{
Nur Alfan Muhammad Zen ${ }^{1 *}$, Edwin de Queljoe ${ }^{1}$, Marina Singkoh $^{1}$
}

1. Program Studi Biologi, Fakultas Matematika dan Ilmu Pengetahuan Alam, Universitas Sam Ratulangi, Manado

*e-mail : alfanmzen30@gmail.com

The aim of this research was to know the bioactivity of Padina australis extract obtained from Molas Coast North Sulawesi against bacterium Staphylococcus epidermidis. The method for the test was MIC Test (Minimum Inhibitory Concentration) and MBC Test (Minimum Bactericidal Concentration). The testing was analyzed with complete randomized design with five treatments namely concentration of $30 \%, 60 \%, 90 \%$, negative control (CMC 1\%) and positive control (cotrimoksazole). Determination of MIC value with turbidity analysis was using spectrophotometer $(\lambda 630 \mathrm{~nm}$ ) while the value of MBC was with pour plate method. Data of MBC test was analyzed with one way ANOVA and Tukey Test. MIC of $P$. australis extract on S. epidermidis is on concentration of $90 \%$. The results of statistical analysis one way ANOVA, of the MBC test showed a significant differrence between the extract with colonies total grown on NA media. Tukey test showed that the extract of $P$. australis performed best bioactivity against S. epidermidis was on concentration of $90 \%$

Keywords : Padina australis, Staphylococcus epidermidis, bioactivity

Penelitian ini bertujuan untuk mengetahui bioaktivitas ekstrak $P$. australis terhadap bakteri $S$. epidermidis. Metode yang digunakan dalam uji bioaktivitas adalah uji Minimum Inhibitory Concentration (MIC) dan uji Minimum Bactericidal Concentration (MBC). Pengujian bioaktivitas dilakukan dengan menggunakan Rancangan Acak Lengkap (RAL) dengan 5 perlakuan yaitu seri konsentrasi ekstrak 30\%, 60\%, 90\%, kontrol negatif (CMC 1\%) dan kontrol positif (cotrimoksazole). Penentuan nilai MIC dengan analisis kekeruhan menggunakan spektrofotometer $(\lambda 630 \mathrm{~nm})$ sedangkan nilai MBC dengan metode pour plate. Data hasil uji MBC dianalisis menggunakan ANOVA one way kemudian dilanjutkan dengan Uji Tukey. Hasil penelitian ini menunjukkan nilai MIC (Kadar Hambat Minimal) adalah konsentrasi $90 \%$. Hasil analisa statistika ANOVA one way data uji MBC menunjukkan terdapat perbedaan yang signifikan antara pemberian ekstrak dengan total koloni yang tumbuh pada media NA. Uji Tukey menunjukkan bahwa ekstrak $P$. australis yang menunjukkan bioaktivitas terbaik terhadap $S$. epidermidis adalah konsentrasi $90 \%$ dengan selisih 631 koloni dengan konsentrasi $60 \%$ dan 658 koloni dengan konsentrasi $30 \%$. Total koloni yang tumbuh pada media NA dengan perlakuan konsentrasi ekstrak $90 \%$ adalah 31 koloni. Ekstrak etanol Padina australis memiliki bioaktivitas dalam menghambat pertumbuhan bakteri $S$. epidermidis. Nilai MIC ekstrak $P$. australis terhadap bakteri $S$. epidermidis adalah konsentrasi $90 \%$. Nilai MBC tidak diketahui dikarenakan pada pengujian lanjut (MBC) konsentrasi yang menunjukkan nilai MIC merupakan konsentrasi tertinggi yaitu $90 \%$ masih ditemukan koloni bakteri yang tumbuh pada media NA.

Kata Kunci : Padina australis, Staphylococcus epidermidis, bioaktivitas 


\section{PENDAHULUAN}

Kelautan yang meliputi hampir $70 \%$ dari seluruh luas permukaan bumi khususnya Indonesia yang dikenal dunia sebagai negara bahari merepresentasikan sumber terbaik bagi kekayaan bahan alam planet ini. Berbagai literatur telah mengemukakan bahwa banyak hasil bahan alam kelautan yang mempunyai bioaktivitas antitumor (Kamiya et al., 1987), antiviral (Rinehart et al., 1993), komponen sitotoksik (Schmitz et al., 1993), dan lain-lain. Studi-studi tersebut telah memperlihatkan bahwa lingkungan kelautan merupakan sumber yang kaya akan komponen bioaktif, diantaranya banyak memiliki struktur kimiawi yang tidak ditemukan di lingkungan terestrial (Jadulco, 2002).

Alga (seaweed) adalah bagian terbesar dari Kingdom Plantae yang hidup di laut, dimana secara morfologi dapat dikelompokkan ke dalam golongan tumbuhan (Thallophyta) karena tidak memiliki perbedaan susunan kerangka seperti akar, batang, dan daun (Aslan, 1998). Riset mengenai alga sebagai bahan sediaan farmasetika telah dilakukan pada beberapa tempat di wilayah Sulawesi Utara diantaranya di perairan pesisir Pulau Nain, perairan Likupang, Tongkaina, dan Malalayang (Singkoh, 2008). Namun beberapa wilayah seperti pesisir pantai Molas, Kota Manado belum banyak diteliti.

Penyakit infeksi merupakan jenis penyakit yang paling banyak diderita oleh penduduk di negara berkembang, termasuk Indonesia. Salah satu penyebab penyakit infeksi adalah bakteri (Radji, 2011). Salah satu bakteri yang dapat menyebabkan infeksi adalah Staphylococcus epidermidis. Saat ini sudah banyak bakteri penyebab penyakit (patogen) pada manusia yang menunjukkan resistensi obat karena penggunaan antibiotik yang tidak sesuai (Sartoratto et al., 2004).

Penelitian ini bertujuan untuk mengetahui bioaktivitas ekstrak Padina australis terhadap bakteri
S. epidermidis. Bioaktivitas dari ekstrak $P$. australis diketahui berdasarkan hasil uji MIC (Minimum Inhibitory Concentration) dan uji MBC (Minimum Bactericidal Concentration).

\section{METODE PENELITIAN}

Penelitian ini dilaksanakan pada bulan Agustus hingga Oktober 2015. Pengambilan sampel di Pesisir Pantai Molas Kecamatan Bunaken Kota Manado Sulawesi Utara. Uji bioaktivitas dilakukan di Laboratorium Mikrobiologi Farmasi FMIPA UNSRAT Manado. Bahan-bahan yang digunakan dalam penelitian ini adalah $\mathrm{MERCK}^{\circledR}$ Nutrient Agar (NA), MERCK ${ }^{\circledR}$ Nutrient Broth, etanol 95\%, CMC, sampel segar $P$. australis Hauck, aluminium foil, kertas whatman No. 1, kain kasa dan kapas steril, CMC, akuades steril, $\mathrm{NaCl} 0,9 \%$, $\mathrm{H}_{2} \mathrm{SO}_{4} 1 \%$, dan $\mathrm{BaCl} 1 \%$.

Sampel segar $P$. australis Hauck yang berasal dari pesisir Pantai Molas Kecamatan Bunaken Kota Manado yang telah diambil dibersihkan dari substratnya dan dicuci hingga bersih. Sampel dipotong-potong kecil kemudian digerus. Sampel yang telah digerus selanjutnya direndam dalam pelarut etanol 95\% dengan perbandingan pelarut dan sampel yaitu 2:1 selama 24 jam kemudian maserat disaring menggunakan kertas whatman no. 1 sehingga diperoleh filtrat pertama. Filtrat pertama disimpan di dalam botol sedangkan ampas sampel direndam kembali dengan pelarut yang sama dengan perbandingan pelarut dan sampel yaitu 2:1. Hal yang sama dilakukan pada maserasi ketiga selama 24 jam. Hasil maserasi yang telah disaring kemudian dikumpulkan dan diuapkan dengan menggunakan alat rotary vacum evaporator pada suhu $45^{\circ} \mathrm{C}$ agar terbentuk ekstrak kental. Hasil ekstrak kental ini merupakan ekstrak dengan konsentrasi $100 \%$ dan untuk mencegah kehilangan senyawasenyawa yang terkandung dalam 
ekstrak, ekstrak harus disimpan pada suhu $18^{\circ} \mathrm{C}$.

Uji bioaktivitas ekstrak etanol $P$. australis dilakukan dengan metode pengukuran turbiditas (kekeruhan) menggunakan analisis spektrofotometer. Untuk menentukan nilai MIC dan nilai MBC dengan metode pour plate. Suspensi bakteri $S$. epidermidis yang digunakan dalam penelitian ini diperoleh dari Laboratorium Mikrobiologi Klinik RSUD. Prof. Dr. Kandou Kota Manado dengan kepadatan $10^{6} \quad \mathrm{CFU} / \mathrm{mL}$. Pembuatan suspensi tersebut distandarisasi dengan menggunakan metode McFarland 0.5 yang terdiri dari $9,95 \mathrm{~mL}$ larutan $\mathrm{H}_{2} \mathrm{SO}_{4} 1 \%$ dan $0,05 \mathrm{~mL}$ larutan $\mathrm{BaCl} 1,175 \%$ yaitu setara dengan kepadatan bakteri $10^{8} \mathrm{CFU} / \mathrm{mL}$ (Sutton, 2011).

Satu tabung berisi larutan standar McFarland 0.5 terlebih dahulu disiapkan. Suspensi bakteri $S$. epidermidis dibuat dengan cara mengambil 4-10 ose bakteri dari media NA yang telah diinkubasi selama 24 jam dimasukkan ke dalam tabung yang berisi $\mathrm{NaCl} 0,9 \%$, kemudian dihomogenkan. Suspensi bakeri tersebut disetarakan kekeruhannya dengan larutan standar McFarland 0.5. Suspensi yang telah dibuat kemudian diencerkan dengan cara memipet $0,1 \mathrm{~mL}$ suspensi bakteri $\left(10^{8} \mathrm{CFU} / \mathrm{mL}\right)$ dimasukkan kedalam tabung steril dan ditambahkan $9,9 \mathrm{~mL}$ larutan $\mathrm{NaCl} 0,9 \%$ sehingga diperoleh kepadatan bakteri uji yakni $10^{6} \mathrm{CFU} / \mathrm{mL}$ (Oonmetta-aree et al., 2005).

Uji MIC dilakukan mengacu pada penelitian Munfaati et al, (2014). Seri konsentrasi ekstrak $P$. australis yang telah diencerkan dengan pelarut CMC $1 \%$ disiapkan terlebih dahulu. Tiga dari lima tabung reaksi steril yang berisi 8,8 $\mathrm{mL}$ Nutrient Broth steril masing-masing ditambahkan $1 \mathrm{~mL}$ ekstrak $P$. australis Hauck dan $200 \mu \mathrm{L}$ kultur bakteri. Pada perlakuan kontrol positif tabung yang berisi $8,8 \mathrm{~mL}$ Nutrient Broth ditambahkan $1 \mathrm{~mL}$ antibiotik cotrimoksazole dan $200 \mu \mathrm{L}$ kultur bakteri. Pada perlakuan kontrol negatif tabung yang berisi $8,8 \mathrm{~mL}$ ditambahkan
$1 \mathrm{~mL}$ CMC 1\% dan $200 \mu \mathrm{L}$ kultur bakteri. Semua tabung divortex agar homogen kemudian diambil $2 \mathrm{~mL}$ untuk diukur nilai Optical Density (OD) bakteri dengan menggunakan spektrofotometer ( $\lambda 630 \mathrm{~nm}$ ).

Kelima tabung di atas diinkubasi selama 18 jam pada suhu $37^{\circ} \mathrm{C}$. Nilai OD pasca inkubasi diukur kembali dengan mengambil $2 \mathrm{~mL}$ untuk diukur nilai OD dengan menggunakan spektrofotometer ( $\lambda 630 \mathrm{~nm}$ ). Jika selisih nilai OD dengan konsentrasi terendah bernilai negatif, maka ditetapkan sebagai Minimum Inhibitory Concentration (MIC).

Uji MBC menggunakan metode pour plate yang mengacu pada penelitian Munfaati et al, (2014) yaitu dengan cara mencairkan Nutrient Agar terlebih dahulu dan menyiapkan cawan petri steril sebanyak 5 buah. Ekstrak $P$. australis dari seri konsentrasi dan juga kontrol dimasukkan kedalam tabung yang berisi Nutrient Broth. Tabung tersebut ditambahkan suspensi bakteri kemudian dihomogenkan dan selanjutnya dituang ke dalam cawan petri steril dan ditunggu hingga media memadat. Setelah itu diinkubasi pada suhu $37^{\circ} \mathrm{C}$. Hasil inkubasi dapat dilihat dengan ada tidaknya pertumbuhan koloni pada Nutrient Agar. Total koloni bakteri dihitung menggunakan Colony Counter. Data hasil penelitian uji MBC (kuantitatif) dianalisis dengan uji ANOVA one way kemudian apabila terjadi perbedaan yang signifikan maka dilanjutkan dengan Uji Tukey.

\section{HASIL DAN PEMBAHASAN}

Pengujian bioaktivitas pada bakteri $S$. epidermidis dilakukan dengan menentukan nilai Minimum Inhibitory Concentration (MIC) atau Kadar Hambat Minimal (KHM) dan Minimum Bactericidal Concentration (MBC) atau Kadar Bunuh Minimal (KBM). Hasil pengukuran nilai OD (optical density) pada uji Minimum Inhibitory Concentration (MIC) menggunakan 
Tabel 1. Hasil Pengukuran Nilai OD pada uji MIC ekstrak Padina australis Hauck terhadap bakteri Staphylococcus epidermidis.

\begin{tabular}{lccc}
\hline \multicolumn{1}{c}{ Perlakuan } & \multicolumn{2}{c}{ Nilai OD } & \multirow{2}{*}{ OD } \\
& Pra Inkubasi & Pasca Inkubasi & \\
\hline $\mathbf{3 0 \%}$ & 0,364 & 0,603 & 0,239 \\
$\mathbf{6 0 \%}$ & 0,423 & 0,680 & 0,257 \\
$\mathbf{9 0 \%}$ & 0,506 & 0,339 & $-0,671$ \\
Kontrol Positif & 0,170 & 0,048 & $-0,122$ \\
Kontrol Negatif & 0,050 & 0,341 & 0,291 \\
\hline
\end{tabular}

spektrofotometer $\left(\begin{array}{lll}\lambda & 630 & \mathrm{~nm}\end{array}\right)$ menunjukkan hambatan pertumbuhan bakteri $S$. epidermidis secara pasti yaitu dengan melihat penurunan nilai OD pra inkubasi dan pasca inkubasi (Munfaati et al., 2014) yang disajikan pada Tabel 1. Nilai Minimum Inhibitory Concentration (MIC) dapat ditentukan dengan mengukur selisih antara nilai OD pra inkubasi dan pasca inkubasi. Nilai $\triangle O D$ negatif menunjukkan adanya penurunan nilai absorbansi yang menandakan terjadinya penurunan jumlah sel yang telah diinkubasi selama 18 jam. Nilai $\triangle O D$ positif menunjukkan tidak adanya penurunan nilai $O D$ yang berarti masih terjadi peningkatan jumlah sel bakteri pasca inkubasi. Nilai $\triangle O D$ yang tersaji dalam Tabel 1 menunjukkan nilai negatif hanya pada konsentrasi ekstrak $90 \%$ yakni sebesar $-0,617$ dan juga perlakuan kontrol positif (cotrimoksazole) sebesar -0,122 pada konsentrasi ekstrak 30\%, 60\%, dan juga kontrol negatif (CMC 1\%) tidak mengalami penurunan nilai $O D$ pasca inkubasi ditandai dengan selisih $\triangle O D$ yang bernilai positif yakni sebesar 0,239 untuk konsentrasi 30\%, 0,257 untuk konsentrasi $60 \%$ dan 0,291 untuk kontrol negatif yang artinya pada konsentrasi $30 \%, 60 \%$ dan perlakuan kontrol negatif (CMC 1\%) tersebut masih terjadi peningkatan pertumbuhan bakteri $S$. epidermidis. Berdasarkan hasil diatas, maka ekstrak $P$. australis Hauck dengan konsentrasi 90\% ditetapkan sebagai Minimum Inhibitory Concentration (MIC) ekstrak etanol $P$. australis Hauck terhadap pertumbuhan bakteri S. epidermidis.

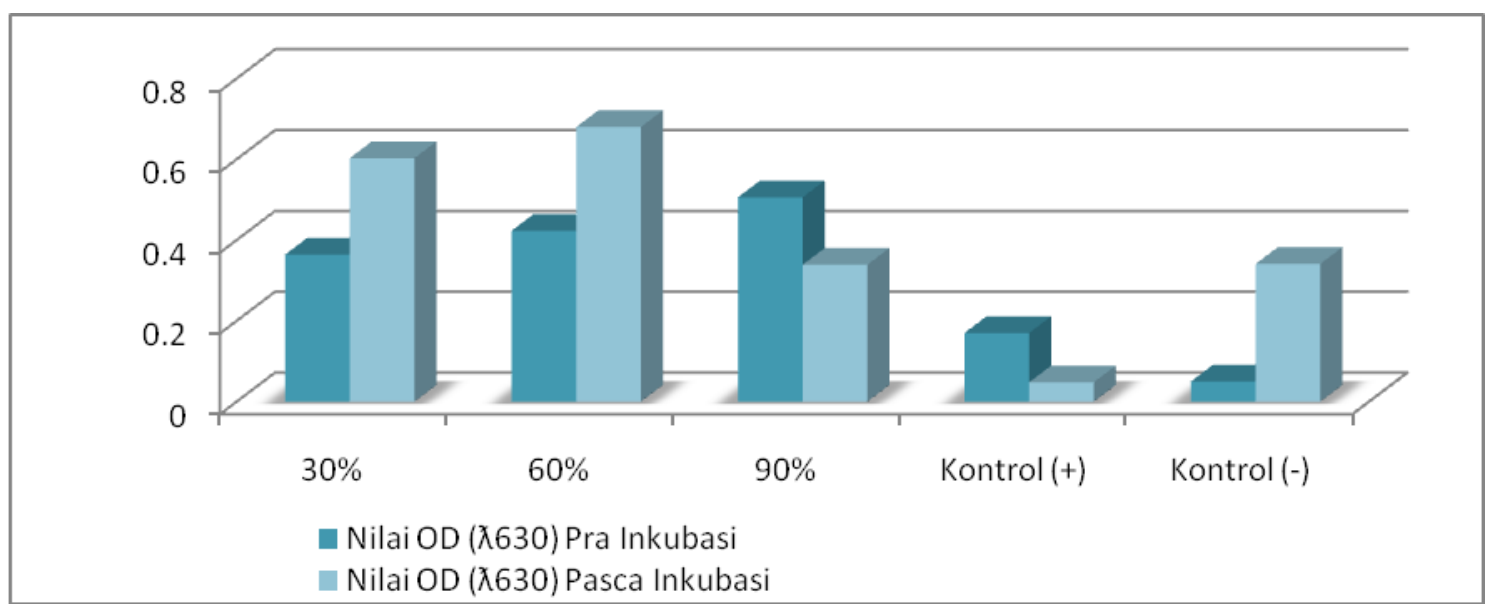

Gambar 1. Hubungan antara nilai OD pemberian tiap seri konsentrasi ekstrak pra dan pasca inkubasi. 
Tabel 2. Hasil Uji MBC ekstrak Padina australis terhadap bakteri Staphylococcus. epidermidis

\begin{tabular}{lccccc}
\hline \multirow{2}{*}{ Perlakuan } & \multicolumn{2}{c}{ Total Koloni (CFU/plate) } & \multirow{2}{*}{ Total } & \multirow{2}{*}{ Rerata } \\
& $U_{\mathrm{I}}$ & $\mathrm{U}_{\|}$ & $\mathrm{U}_{\mathrm{III}}$ & & $662 \pm 35,09$ \\
\hline $\mathbf{3 0 \%}$ & 633 & 652 & 701 & 1986 & $689 \pm 70,95$ \\
$\mathbf{6 0 \%}$ & 752 & 702 & 612 & 2066 & $31 \pm 1,00$ \\
$\mathbf{9 0 \%}$ & 30 & 31 & 32 & 93 & 0 \\
Kontrol (+) & 0 & 0 & 0 & 0 & $736 \pm 35,53$ \\
Kontrol (-) & 771 & 700 & 738 & 2209 & \\
\hline
\end{tabular}

Hasil pengujian MBC dengan menggunakan metode pour plate berupa jumlah koloni bakteri $S$. epidermidis yang tumbuh pada media NA tersaji pada Tabel 2. Data pada tabel 2 menunjukkan bahwa jumlah ratarata koloni yang tumbuh pada media NA paling banyak pada kontrol negatif (tanpa pemberian ekstrak $P$. australis) yaitu sebanyak 736 koloni sedangkan jumlah rata-rata koloni paling sedikit terdapat pada kontrol positif (cotrimoksazole) yakni sebanyak 0 koloni dan konsentrasi 90\% sebanyak 31 koloni. Hasil uji MBC dianalisis secara statistika dengan menggunakan uji ANOVA (Analysis of Varians) one way dengan taraf kepercayaan $95 \%$ dan diperoleh nilai $F_{\text {Hitung }}=199.047>$ nilai $\mathrm{F}_{\text {table }}=5.14\left(\mathrm{H}_{0}\right.$ ditolak $=$ hipotesa nihil $)$.
Hal ini menunjukkan bahwa ada perbedaan yang signifikan antara perlakuan seri konsentrasi uji ekstrak $P$. australis terhadap total koloni $S$. epidermidis yang tumbuh pada media NA.

Berdasarkan Uji Tukey dapat dilihat total koloni pada konsentrasi 30\% lebih kecil 26,667 koloni dibandingkan total koloni pada konsentrasi $60 \%$ dan lebih besar 631,000 koloni pada konsentrasi $90 \%$. Total koloni yang tumbuh pada konsentrasi $60 \%$ lebih besar 657,667 koloni dengan koloni yang tumbuh pada konsentrasi $90 \%$. Total koloni yang tumbuh pada konsentrasi 90\% lebih kecil 657,667 koloni dari total koloni yang tumbuh pada konsentrasi $60 \%$ sehingga dari keseluruhan pernyataan

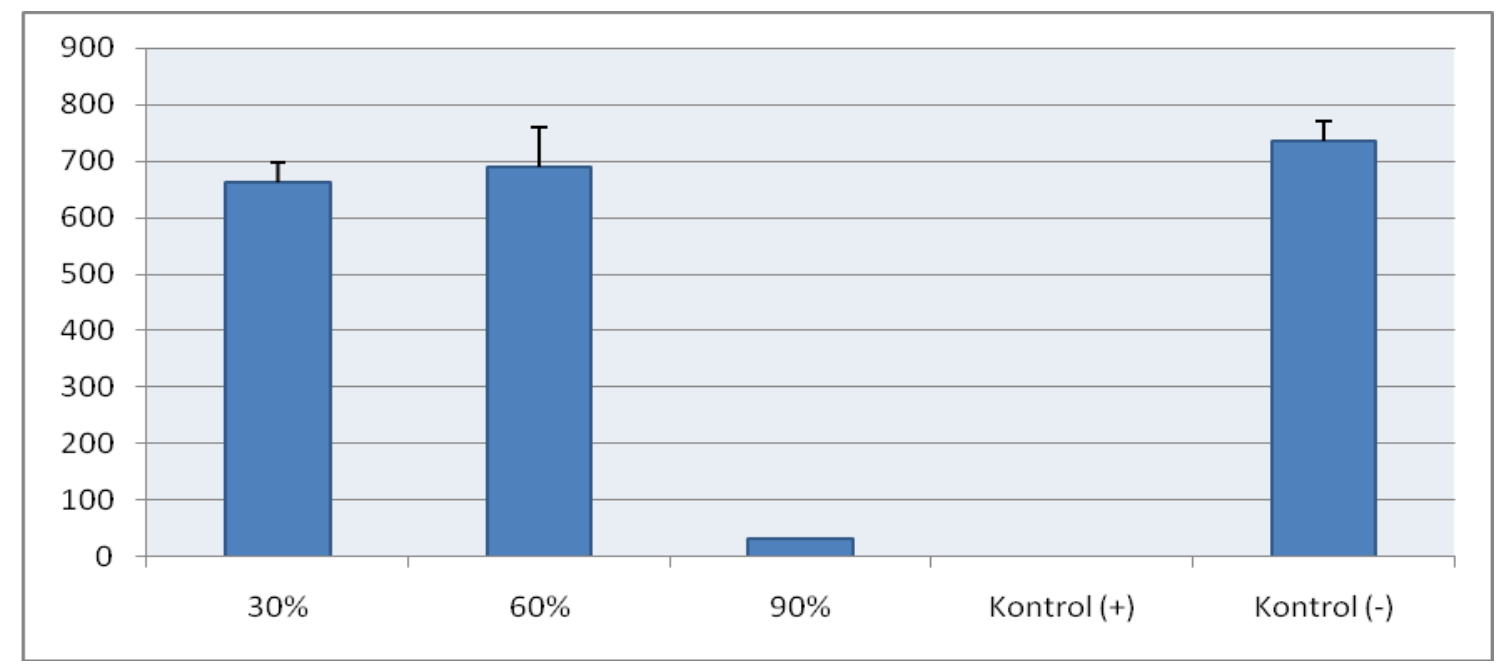


Gambar 2. Rata-rata total koloni pada setiap perlakuan.

di atas menimbulkan interpretasi bahwa konsentrasi ekstrak $P$. australis yang paling baik digunakan dalam menghambat pertumbuhan bakteri S. epidermidis adalah konsentrasi $90 \%$. Penurunan jumlah koloni bakteri $S$. epidermidis dalam penelitian ini disebabkan oleh aktivitas biologis (antibakteri) senyawa bioaktif yang terkandung dalam ekstrak etanol $P$. australis. Beberapa penelitian sebelumnya telah melaporkan senyawa bioaktif seperti golongan steroid dan terpenoid yang terkandung dalam ekstrak $P$. australis berperan besar dalam menghambat pertumbuhan mikroba seperti bakteri.

\section{KESIMPULAN}

Ekstrak etanol Padina australis memiliki bioaktivitas dalam menghambat pertumbuhan bakteri Staphylococcus epidermidis. Nilai MIC ekstrak $P$. australis terhadap bakteri $S$. epidermidis adalah konsentrasi 90\%. Nilai MBC tidak diketahui dikarenakan pada pengujian lanjut (MBC) konsentrasi yang menunjukkan nilai MIC merupakan konsentrasi tertinggi yaitu $90 \%$ masih ditemukan koloni bakteri yang tumbuh pada media NA.

\section{DAFTAR PUSTAKA}

Aslan, L.M. 1998. Budidaya Rumput Laut. Penerbit Kanisius. Yogyakarta. 96 hal.

Jadulco, R.C. 2002, Isolation and Structure Elucidation of Bioactive Secondary Metabolites from Marine Sponges and Spongederived Fungi. Dissertation of Doktor grades, University of Wuerzburg. p 176.

Kamiya, H., Endo, Y., Muramoto, K., Uchida, H., Sasaki, T., Uchida, N,A., Raj, U. 1987. Antitumor
Activity of the Macromolecul Fraction from a Fijian Tunicate Didemnum varians. Nippon Suisan Gakkaishi 53 (3): 493-496.

Munfaati, P. N., Evie, R., Guntur, M. 2014. Aktivitas Senyawa Antibakteri Ekstrak Herba Meniran (Phyllanthus niruri) terhadap Pertumbuhan Bakteri Shigella dysenteriae Secara in Vitro. Lantera Bio.

Oonmetta-aree, J., Suzuki, T., Gasaluck, P., Eumkeb, G. 2005. Antimicrobial properties and action of galangal (Alpinia galanga Linn.) on Staphylococcus aureus. ELSEVIER. 1214-1220 pp.

Radji, M. 2011. Buku Ajar Mikrobiologi Panduan Mahasiswa Farmasi dan Kedokteran, 14, 35, 107, 194, Jakarta, Penerbit Buku Kedokteran EGC.

Rineheart, K. L., Shield, L. S., CohenParsons, M. 1993. Antiviral subtances. In: Marine Biotechnology, Vol. 1. Pharmaceutical and Boactive Natural Products, Attaway, D.H., Zaborsky, O.R. (eds). Plennum Press: New York and London; 309-342 pp.

Sartoratto, A., Machado, Ana Lúcia M., Delarmelina, C., Figueira G. M., Marta Cristina T. Duarte, Vera Lúcia, Rehder, G.. 2004. Composition and Antimicrobial Activity of Essential Oil From Aromatic Plants Used In Brazil. Brazilian Journal of Microbiology (2004) 35: 275-280.

Schmitz, F. J., Bowden, B. F., Toth S. I. 1993. Antitumor and cytotoxic compounds from marine organism. In: Marine Biotechnology Vol. 1. 
Pharmaceutical and Bioactive Natural Products, Attaway, D.H., Zaborsky, O.R., (eds). Plenum Press: New York and London; 197-308 pp.

Singkoh, M. F. O. 2008. Uji Farmasitika pada Alga Laut Gracilaria edulis (S. G. Gmelin) P. C. Silva, Caulerpa racemosa (Forsskal) $J$. Agardh, Boergesenia forbesii (Harvey) J. Feldmann, Halimeda macroloba Decaisne dari Perairan Pulau Nain Kabupaten Minahasa Utara Sulawesi. Tesis. Program Pascasarjana, Universitas Sam Ratulangi Manado.

Sutton, S. 2011. Measurement of Microbial Cells by Optical Density. Journal of Validation Technology. 17: 46-49. 